\title{
Efficient particle bombardment-mediated transformation of Cuban soybean (INCASoy-36) using glyphosate as a selective agent
}

\author{
Natacha Soto $^{1} \cdot$ Celia Delgado $^{1} \cdot$ Yuniet Hernández $^{1} \cdot$ Yamilka Rosabal $^{1}$. \\ Aleines Ferreira $^{1} \cdot$ Merardo Pujol $^{1} \cdot$ Francisco J. L. Aragão $^{2} \cdot$ Gil A. Enríquez $^{1}$
}

Received: 23 March 2016 / Accepted: 21 September 2016 / Published online: 27 September 2016

(C) Springer Science+Business Media Dordrecht 2016

\begin{abstract}
Soybean is highly affected by weeds in tropical countries, causing significant losses in yields. Transgenic herbicide resistant soybeans have been produced in a limited number of varieties and parental lines. This study was conducted to obtain glyphosate herbicide resistant transgenic soybean plants through particle bombardment of embryonic axes in a Cuban variety. Shoot regeneration in $25 \mathrm{mg} / \mathrm{L}$ of glyphosate occurred within a short period and plantlets developed roots in a medium without selection pressure, which favored the in vitro growth of plants at a transformation frequency of 3.1-6.0\%. Expression and integration of the cp4epsps gene was confirmed in the progeny by an immune-detection assay, PCR and Southern blot. All greenhouse evaluated transgenic soybean lines $\left(T_{1}\right)$ displayed tolerance to $1.25 \mathrm{Kg} / \mathrm{ha}$ of glyphosate. Growth and seed development of transformed plants was similar to untransformed plants. The regeneration procedure using embryonic axes combined with the efficient selection of shoots in glyphosate enabled the production of transgenic plants of this Cuban genotype, showing high tolerance to the herbicide, good efficiency and reproducibility.
\end{abstract}

Natacha Soto

natacha.soto@cigb.edu.cu

1 Soybean Biotechnology Laboratory, Plant Biotechnology Department, Center for Genetic Engineering and

Biotechnology, Ave. 31 e/ 158 \& 190, Playa, A.P. 6162, CP 10600 Havana, Cuba

2 Laboratório de Engenharia Genética Aplicada à Agricultura Tropical, Embrapa Recursos Genéticos e Biotecnologia (Cenargen), Parque Estação Biológica, Final Av. W3 Norte, Brasília DF 70770-900, Brazil
Keywords Bombardment transformation - Embryonic axes · Glyphosate selection · Soybean (Glycine max) · Transgenic plants

\section{Introduction}

Soybean [Glycine max (L.) Merr.] is an important source of protein and oil with domestic uses and industrial applications. In the last 5 years there has been a notable increase in soybean production in Cuba, with areas using more modern cultivation methods (Menéndez et al. 2014). This legume significantly benefits other crops since it contributes to nitrogen fixation in the soil during crop rotation (Ferguson 2013). In tropical countries, soybean is affected by the high occurrence of weeds causing significant losses in yields. Weeds are normally controlled by selective herbicides, which require complex application strategies and involves relevant costs. Transgenic herbicide resistant soybean events have therefore been generated in a limited number of varieties and parental lines (Padgette et al. 1995; Clemente et al. 2000; Guo et al. 2015). It is noteworthy that the development of transgenic soybean is not a routine process, mainly because of its low regeneration capacity and due to the few useful selection markers available for the efficient production of transgenic plants (Dang and Wei 2007; Rech et al. 2008; Wiebke-Strohm et al. 2011).

Several types of soybean tissues have been used as explants for plant transformation. Shoot regeneration is, however, highly dependent on the genotype (Parrott et al. 1989; Simmonds and Donaldson 2000; Mariashibu et al. 2013; Verma et al. 2014). Therefore, the selection of cultivars and explants is important in this process. Two methods have been used for the genetic transformation of soybean; Agrobacterium tumefaciens-mediated transformation 
(Hinchee et al. 1988; Zhang et al. 2000; Olhoft et al. 2004; Paz et al. 2006; Yang et al. 2016) and particle bombardment (McCabe et al. 1988; Aragão et al. 2000; Rech et al. 2008; de Paiva Rolla et al. 2014). Both strategies have been somewhat successful in producing stably transformed plants (Homrich et al. 2012). The combination of both transformation methods has also been proposed (Droste et al. 2000; Wiebke-Strohm et al. 2011).

Gene delivery into meristematic cells by particle bombardment has been considered to be more genotype-independent for the transfer of foreign DNA into soybean (Aragão et al. 2000; Rech et al. 2008; Homrich et al. 2012). Particle bombardment is a physical process of gene delivery and any plant tissue can theoretically be transformed by this method (Christou 1996). Somatic embryos (Finer and McMullen 1991; Droste et al. 2002; Finer and Larkin 2008; Kanizay et al. 2015) and embryonic axes of seeds (Rech et al. 2008; Cunha et al. 2011) are the most frequently used explants.

Previous studies supported the idea that most of the foreign genes introduced by the biolistic system are normally transmitted to the progeny (Christou et al. 1989). Nonetheless, the particle bombardment-mediated transformation of soybean shoot tips in the absence of selection could often result in chimeric plants, which may or may not transmit the transgenes to the subsequent generation (Finer and McMullen 1991; Aragão et al. 2000). McCabe et al. (1988) reported that transgenic soybean plants obtained from embryonic axes that were bombarded and regenerated in a medium without any selective agent showed very low transformation efficiency. The use of an efficient selectable marker enables the regeneration of non-chimeric plants and increases transformation efficiency. A higher transformation frequency was demonstrated by bombarding embryonic soybean axes using the imazapyr herbicide as the selection marker (Aragão et al. 2000; Rech et al. 2008). This type of herbicide is concentrated in the apical meristematic region and enables cell selection without deleterious effects on the embryonic axes (Rech et al. 2008). Other molecules that are able to translocate through the embryonic axes and concentrate in the meristematic cells, such as glyphosate (Mollenhauer et al. 1987; Aragão et al. 2005; Shaner 2009; Dill et al. 2010), could also be assessed for the selection of transgenic cells in the apical meristem.

The herbicide, glyphosate, acts on a broad spectrum of plant species. Its tolerance was obtained by the expression of the 5-enol-pyruvyl-shikimate-3-phosphate synthase (EPSPS) coding gene from the Agrobacterium $s p$ strain CP4 (Padgette et al. 1995; Dill et al. 2008; Horak et al. 2014). The glyphosate tolerant EPSPS enzyme introduced into the plant covers the need for aromatic amino acids and other metabolites that are essential for the development and growth of the plant in the presence of the herbicide (Padgette et al. 1995;
Cobb and Reade 2010). In tolerant transgenic crops farmers can use glyphosate as a post emergence herbicide against weeds (Dill et al. 2008).

Studies for the genetic improvement of soybean in Cuba have led to the development of new genotypes such as INCASoy-36 adapted to local conditions with excellent agronomic characteristics (Ortiz et al. 2008). Mastering a soybean genetic transformation methodology adapted to Cuban genotypes is of great importance, because this would enable us to introduce several genes with relevant agronomic characteristics. Here we show the integration and expression of the cp4epsps gene in soybean plants of the INCASoy-36 cultivar, transformed by particle bombardment. For the first time in a Cuban variety, transgenic plants were efficiently obtained from transformed zygotic embryonic axes selected with glyphosate. These results can have a significant impact in speeding up Cuban soybean breeding programs.

\section{Materials and methods}

\section{Plant material and explant preparation}

Mature soybean seeds (Glycine max (L) Merrill) of the INCASoy-36 Cuban cultivar supplied by the National Institute of Agricultural Sciences (INCA, according to its Spanish acronym) were used in these experiments. The seeds were surface-sterilized in $70 \%$ ethanol for $1 \mathrm{~min}$ followed by immersion in $12 \%$ sodium hypochlorite solution for $5 \mathrm{~min}$. Seeds were then rinsed three times in sterile distilled water and soaked in sterile water for $26-28 \mathrm{~h}$ in the dark at $28^{\circ} \mathrm{C}$. Seed hulls were removed and carefully separated to extract the embryonic axes without the primary leaves, which were used as the explants.

\section{In vitro sensitivity to glyphosate}

Explants were placed (embedded) in a shoot induction medium (MI) (MS salts (Murashige and Skoog 1962), B5 vitamins (Gamborg et al. 1968), $30 \mathrm{~g} / \mathrm{L}$ sucrose, $5 \mathrm{mg} / \mathrm{L}$ benzylaminopurine, $\mathrm{pH} 5.7$ with $6 \mathrm{~g} / \mathrm{L}$ phytoagar), and cultured in the dark at $26-27^{\circ} \mathrm{C}$. After $48 \mathrm{~h}$ of induction, the explants were moved to a MSB5 medium (MS salts, B5 vitamins, $30 \mathrm{~g} / \mathrm{L}$ sucrose, pH 5.7 with $7 \mathrm{~g} / \mathrm{L}$ phytoagar) supplemented with glyphosate $(5,10,15,20,25$ and $30 \mathrm{mg} / \mathrm{L})$, and kept for $18 / 6 \mathrm{~h}$ under a light/dark regime. Sensitivity to the herbicide was evaluated 60 days later.

\section{Particle bombardment mediated-transformation}

The pCP4EPSPS vector containing the cp4epsps gene (coding for 5-enol pyruvyl-shikimate-3-phosphate synthase) 
under the transcriptional control of the double $35 \mathrm{~S}$ promoter and the $35 \mathrm{~S}$ terminator was used to obtain glyphosate tolerant transgenic soybean plants. This vector was initially made by cloning the cp4epsps gene into the SmaI and EcoRI sites of the pCambia 3300 vector (CAMBIA, Australia). The cp4epsps gene was amplified from a commercial Roundup resistant soybean plant.

Bombardment was performed using a Biolistic PDS1000 Particle Delivery System (Bio-Rad) according to the instruction manual. The embryonic axes were placed with the apical region upward in Petri dishes containing the MS medium immediately before the bombardment. Each plate with the embryonic axes was bombarded with a pressure of $1200 \mathrm{psi}$ and a distance of $3 \mathrm{~cm}$. Bombardment was prepared following the protocol described by Aragão et al. (1996) with modifications. The bombarded explants and controls were immediately immersed in the MI medium for $48 \mathrm{~h}$ at $26-27^{\circ} \mathrm{C}$ in the dark.

\section{GUS expression analysis}

Embryonic axes bombarded with pCambia 2301 and maintained in the MI medium for $48 \mathrm{~h}$ were histochemically examined according to Jefferson (1987). Chlorophyll was removed from the tissue by incubating in $95 \%$ ethanol and the explants were observed by stereoscopy for blue staining. The transformation frequency (the number of explants with blue staining divided by the number of bombarded explants) was calculated.

\section{Selection and regeneration of glyphosate tolerant plants}

After $48 \mathrm{~h}$ in the MI medium, explants bombarded with pCP4EPSPS were transferred to the MSB5 medium supplemented with $25 \mathrm{mg} / \mathrm{L}$ glyphosate. Two controls were used, one with glyphosate selection and another one without selection. All explants were maintained on a photoperiod of $16 \mathrm{~h}$ light $8 \mathrm{~h}$ dark and $25-27^{\circ} \mathrm{C}$. When the regenerated shoots reached 3-4 cm, they were separated from the initial explant, and transferred to the RM medium (MS salts, B5 vitamins, $30 \mathrm{~g} / \mathrm{L}$ sucrose, $7 \mathrm{~g} / \mathrm{L}$ phytoagar, $3 \mathrm{~g} / \mathrm{L}$ charcoal and $\mathrm{pH}$ 5.7) without selection for a period of 10-15 days until roots were formed. Rooted $\mathrm{T}_{0}$ plants were planted in small plastic pots with a mixture of organic matter and zeolite $(1: 1)$. These plants were covered with a plastic bag to create a wet chamber, and maintained under controlled conditions of light and temperature for 7 days. The plants were then transplanted to large pots and kept in a greenhouse for flowering and seed production ( $\mathrm{T}_{1}$ generation). The cultures were periodically observed and the regeneration in glyphosate was evaluated.

\section{Expression of CP4 EPSPS protein in putative transgenic plants}

The expression analysis of the pCP4EPSPS protein in glyphosate tolerant plants $\left(\mathrm{T}_{0}\right)$ was performed by Roundup Ready $^{\circledR}$ immunodetection Kit (Agdia), using discs from young leaves of each putative transformation event, and the untransformed control. The number of positive transformations was determined.

\section{Assessment of sensitivity to glyphosate under greenhouse conditions}

All $\mathrm{T}_{1}$ seeds from 10 randomly selected transgenic lines and 20 seeds from the non-transgenic controls were germinated in pots containing a mixture of organic matter and zeolite (1:1), under natural conditions of light and trickling irrigation. When $\mathrm{T}_{1}$ plants developed their second trifoliate leaf, they were sprayed with glyphosate $(360 \mathrm{~g} / \mathrm{L})$, at a dose of $1.25 \mathrm{Kg} /$ ha (field rate). Sensitive plants were evaluated 1 week after glyphosate treatment.

The analysis of the $T_{1}$ generation transformants (selfpollinated plants) was carried out by testing the sensitivity to the glyphosate herbicide, as described. Chi square $\left(\chi^{2}\right)$ analyses were performed to determine if the observed segregation ratio was consistent with a Mendelian ratio of $3: 1$ (for one locus) or 15:1 (for two loci).

\section{PCR analysis}

Total genomic DNA was isolated from leaves of all herbicide tolerant lines ( $T_{1}$ and $T_{2}$ generation) that had been previously selected with glyphosate, as well as the untransformed control using the CTAB procedure (Doyle and Doyle 1987). The specific primer sequences: sense 5'-GGATTTCAGCATCAGTGGCTACAGC-3' and antisense 5'-GCGGGTTGATGACTTCGATGTCG-3' were utilized for gene detection in the $\mathrm{T}_{1}$ progeny using a Master cycler gradient Eppendorf tube (I-PQ 533101). PCR was performed in a volume of $25 \mu \mathrm{L}$, and the reaction mixture consisted of $10 \mathrm{mM}$ of Go Taq Green $5 \times$ buffer (Promega); $10 \mathrm{mM}$ of dNTPs, $0.2 \mathrm{mM}$ of each primer, $5 \mathrm{U}$ of Go Taq DNA Polymerase I enzyme (Promega), and $600 \mathrm{ng}$ of the template DNA. The PCR reaction was started by an initial denaturing step at $95^{\circ} \mathrm{C}$ for $3 \mathrm{~min}$, and continued with 30 cycles of the following profile: denaturing at $95^{\circ} \mathrm{C}$ for $1 \mathrm{~min}$, annealing at $65^{\circ} \mathrm{C}$ for $1 \mathrm{~min}$, synthesis at $72^{\circ} \mathrm{C}$ for $1 \mathrm{~min}$, followed by an extension at $72{ }^{\circ} \mathrm{C}$ for $10 \mathrm{~min}$. The amplified product was analyzed in $0.8 \%$ agarose, stained with etidium bromide and $1 \times \mathrm{TBE}$ buffer. 


\section{Southern blot analysis}

Southern blot and hybridization were made according to the protocol described by Sambrook et al. (1989). Genomic DNA $(15 \mu \mathrm{g})$ from the $\mathrm{T}_{2}$ generation selected in glyphosate was digested with $K p n I$. The digested DNA was electrophoresed on a $0.8 \%$ agarose gel blotted onto a nylon membrane (Hybond $\mathrm{N}$, Amersham Biosciences). Hybridization was carried out with a-[32P]-dATP-labeled cp4epsps gene as the probe, using the DNA random primer labeling kit (Pharmacia Biotech). The probe was obtained by PCR with cp4epsps gene specific primers to generate the $887 \mathrm{bp}$ fragment. It was isolated from a $1 \%$ agarose gel and purified using the SV Gel Wizard Clean-Up System (Promega).

\section{Results}

\section{Optimized transient transformation}

In this report, the conditions for the delivery of particles coated with the plasmid according to the transient expression were successfully optimized with pCambia 2301 . The $\beta$-glucuronidase (GUS) system is widely used to optimize transformation protocols. GUS histochemical assay confirmed the presence of enzyme activity in 56 out of 100 bombarded explants, after $48 \mathrm{~h}$ in $5 \mathrm{mg} / \mathrm{L}$ (Fig. 1a). An increased transient expression in the apical meristem was observed in our experiments when the explants were bombarded two or three times. Control explants showed no staining.
Table 1 Sensitivity to different concentration of glyphosate in soybean plants

\begin{tabular}{lllll}
\hline $\begin{array}{l}\text { Glyphosate concentra- } \\
\text { tion (mg/L) }\end{array}$ & Total explants & $\begin{array}{l}\text { Explants with } \\
\text { normal shoots }\end{array}$ & $\begin{array}{l}\text { Explants with small } \\
\text { shoots and leaves }\end{array}$ & $\begin{array}{l}\text { Frequency of } \\
\text { regeneration (\%) }\end{array}$ \\
\hline 0 & 25 & 23 & 0 & 92 \\
5 & 25 & 18 & $1^{\mathrm{a}}$ & 76 \\
10 & 25 & 5 & $6^{\mathrm{a}}$ & 44 \\
15 & 25 & 0 & $4^{\mathrm{a}}$ & 16 \\
20 & 50 & 0 & $3^{\mathrm{b}}$ & 6 \\
25 & 50 & 0 & 0 & 0 \\
30 & 50 & 0 & 0 & 0 \\
\hline
\end{tabular}

${ }^{a}$ Explants developing small shoots and leaves after 35 days in MSB5 with glyphosate

${ }^{\mathrm{b}}$ Explants developing small shoots and leaves after 50 days in MSB5 with glyphosate
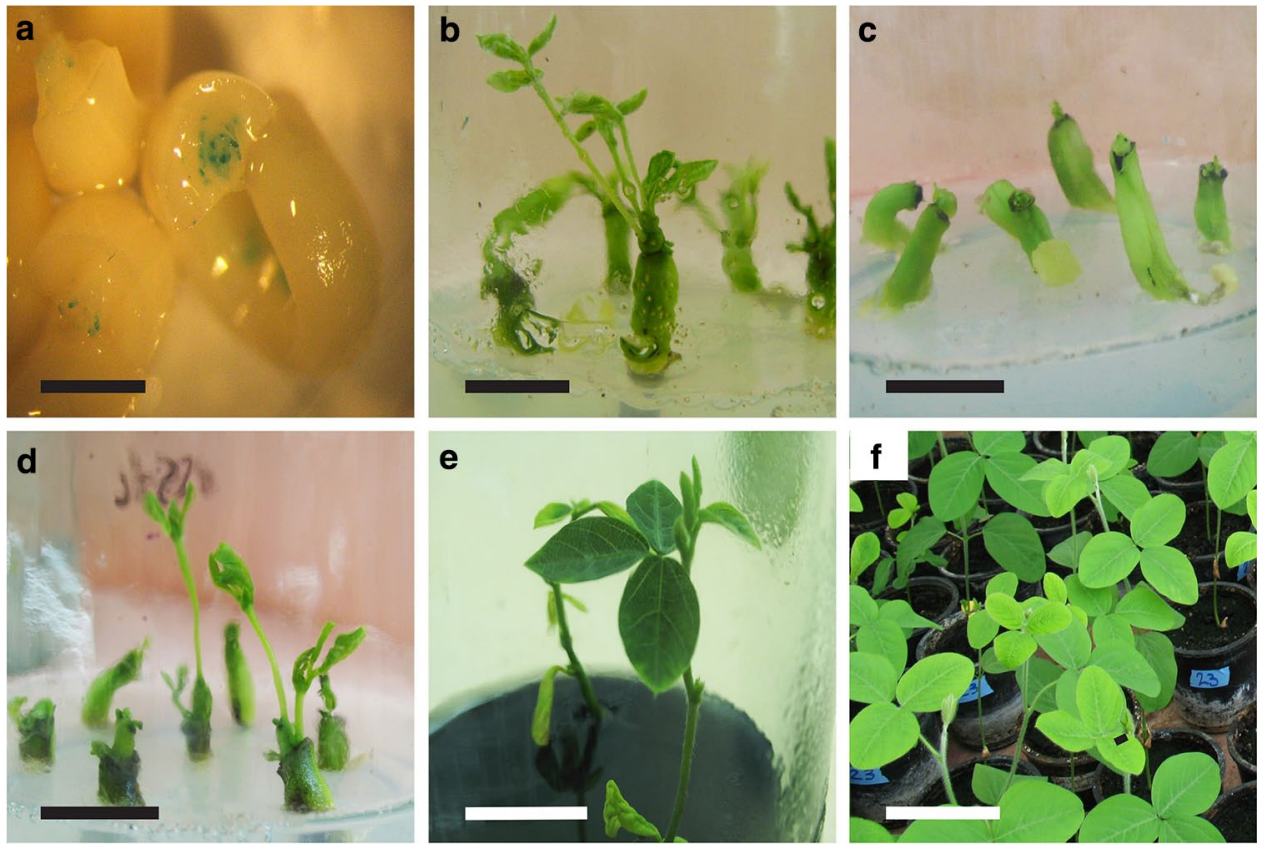


\section{Efficient selection of soybean plants regenerated in glyphosate}

Sensitivity to glyphosate was evident with more than $15 \mathrm{mg} / \mathrm{L}$ of the herbicide, where only $16 \%$ of the embryonic axes showed shoots and leaves after 35 days (Table 1). All embryonic axes maintained their green color as explants in the positive control without glyphosate (Fig. 1b, c). In $20 \mathrm{mg} / \mathrm{L}$ of glyphosate, $6 \%$ shoot regeneration was observed after 50 days. There was no morphogenesis in explants with $25 \mathrm{mg} / \mathrm{L}$ of glyphosate until 60 days (Table 1) and $100 \%$ of them remained green. In this concentration, some explants exhibited necrosis at the apical region as shown in Fig. 1c. On the other hand, unselected plants used as the positive control, showed $100 \%$ shoot regeneration in the MSB5 medium. Since the embryonic axes were sensitive to glyphosate at $25 \mathrm{mg} / \mathrm{L}$ in the MSB5 medium, this concentration was used for the selection of transgenic shoots.

The apical regions of embryonic axes were bombarded with the pCP4EPSPS plasmid. Multiple shoots were induced after $48 \mathrm{~h}$ in $5 \mathrm{mg} / \mathrm{L}$ benzylaminopurine and then sub-cultured to the MSB5 medium with $25 \mathrm{mg} / \mathrm{L}$ of glyphosate, under a 16 h-of-light photoperiod. The development of well-defined shoots $(2 \mathrm{~cm})$ was observed after 10 days in MSB5 in the positive control without selection (Fig. 1b). The negative control in the MSB5 with selection showed no morphogenesis and remained green (Fig. 1c). In these experiments the meristematic tissues of embryonic axes were bombarded only once, which was enough to achieve tolerant shoots without damaging the explants. Results show that 32 out of $705(4.5 \%)$ bombarded explants developed shoots in the presence of the herbicide, showing a transformation frequency (defined as the total number of explants with tolerant shoots divided by the total number of bombarded explants) ranging from 3.1 to $6.0 \%$ (Table 2). After 15-20 days under selection, the first tolerant shoots from explants appeared through direct organogenesis (Fig. 1d). All regenerated shoots reached 3-4 $\mathrm{cm}$ and were transferred to the

Table 2 Experimental results of particle bombardment with the pCP4 EPSPS plasmid to obtain transgenic soybean plants

\begin{tabular}{lllll}
\hline Experiments & $\begin{array}{l}\text { Number } \\
\text { of bom- } \\
\text { barded } \\
\text { explants }\end{array}$ & $\begin{array}{l}\text { Number of } \\
\text { explants with } \\
\text { shoots in } \\
\text { glyphosate }\end{array}$ & $\begin{array}{l}\text { Number } \\
\text { of shoots } \\
\text { selected in } \\
\text { glyphosate }\end{array}$ & $\begin{array}{l}\text { Transfor- } \\
\text { mation } \\
\text { frequency } \\
(\%)^{\mathrm{a}}\end{array}$ \\
\hline 1 & 185 & 7 & 10 & 3.8 \\
2 & 160 & 5 & 8 & 3.1 \\
3 & 183 & 11 & 13 & 6.0 \\
4 & 177 & 9 & 15 & 5.1 \\
Total & 705 & 32 & 46 & \\
\hline
\end{tabular}

${ }^{a}$ Transformation frequency $(\%)=($ the number of explants with shoots in glyphosate)/(the number of bombarded explants) $\times 100$ rooting medium (RM) without selection. After 15 days, 46 plantlets had rooted and showed a similar phenotype to non-transgenic plants (Fig. 1e). Plantlets developed a main root with secondary roots, even with root hairs, favoring the growth and formation of new leaves within a very short time period (10-15 days).

Soybean plants that were transferred to pots were acclimated and kept under greenhouse conditions until harvesting the $T_{1}$ seed (Fig. 1f). Only two plantlets were not adapted and died. After plants reached maturity, they all showed normal phenotypes; they were fertile and produced pods and seeds.

All 46 putative transgenic lines $\left(\mathrm{T}_{0}\right)$ were tested for the presence of the CP4EPSPS protein. Our results showed

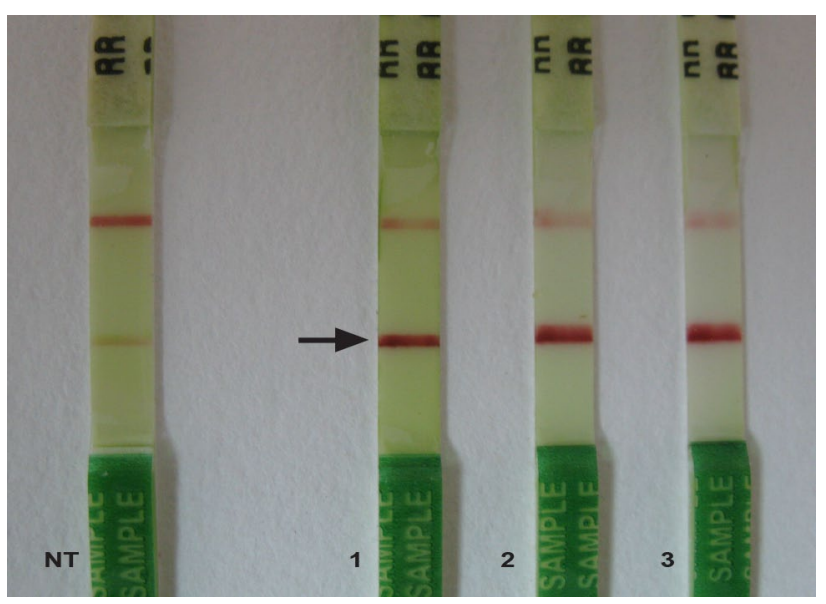

Fig. 2 Test performed for detection of CP4EPSPS protein by inmunodetection kit Roundup Ready ${ }^{\circledR}$ (Agdia). NT Non-transformed plant INCASoy-36; 1-3 Transformed lines positive to the expression of the protein CP4EPSPS; black arrow shown positive line

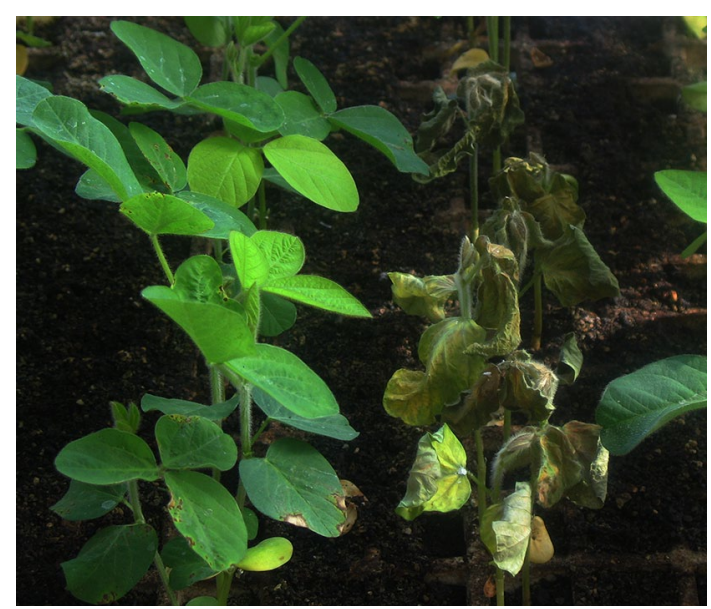

Fig. 3 Evaluation of putative transgenic soybean plants for glyphosate tolerance. Transgenic plants $\left(\mathrm{T}_{1}\right) 1$ week after sprayed with glyphosate herbicide $(1.25 \mathrm{Kg} / \mathrm{ha})$ under greenhouse conditions (left). Non-transgenic plants affected for glyphosate (right) 
that $100 \%$ of the plants that regenerated in the herbicide were positive for this test, which was demonstrated by the Roundup Ready ${ }^{\circledR}$ immunodetection strip (Fig. 2).

\section{High tolerance to the glyphosate herbicide in transgenic soybean plants}

As soon as the plantlets from the $T_{1}$ generation developed their second trifoliate leaf, they were sprayed with glyphosate at a concentration of $1.25 \mathrm{Kg} / \mathrm{ha}$. More than $70 \%$ of plants evaluated in each transgenic line showed a high

Table 3 Segregation of the $T_{1}$ generation of transgenic soybean lines transformed with the pCP4EPSPS vector

\begin{tabular}{llcccc}
\hline Transgenic lines & $\begin{array}{l}\text { Tolerant } \\
\text { plants }\end{array}$ & $\begin{array}{l}\text { Sensitive } \\
\text { plants }\end{array}$ & $\begin{array}{l}\text { Segregation } \\
\text { ratio }^{\mathrm{a}}\end{array}$ & $\chi^{2}$ & $P^{\mathrm{b}}$ \\
\hline 1 & 29 & 4 & $3: 1$ & 2.92 & 0.08 \\
& & & $15: 1$ & 1.94 & 0.16 \\
2 & 35 & 9 & $3: 1$ & 0.48 & 0.49 \\
3 & 22 & 5 & $3: 1$ & 0.60 & 0.44 \\
14 & 21 & 8 & $3: 1$ & 0.10 & 0.75 \\
15 & 31 & 12 & $3: 1$ & 0.19 & 0.66 \\
18 & 16 & 5 & $3: 1$ & 0.01 & 0.90 \\
19 & 28 & 9 & $3: 1$ & 0.01 & 0.92 \\
27 & 30 & 14 & $3: 1$ & 1.09 & 0.30 \\
29 & 41 & 11 & $3: 1$ & 0.41 & 0.52 \\
33 & 37 & 5 & $3: 1$ & 3.84 & 0.05 \\
& & & $15: 1$ & 2.29 & 0.13 \\
\hline
\end{tabular}

${ }^{\mathrm{a}}$ Data are based on tolerance to glyphosate herbicide in a greenhouse ${ }^{\mathrm{b}} P$ is the probability that observed ratios reflect the expected segregation ratio of $3: 1$ or $15: 1$

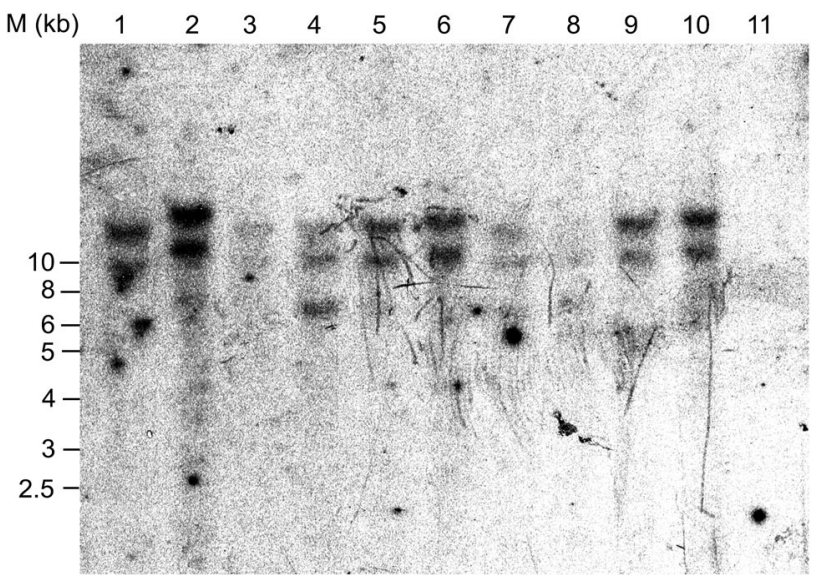

Fig. 6 Southern blot hybridization analysis of 10 soybean transgenic clones. DNAs were digested with KpnI transferred to a nylon membrane and probed with an internal fragment of the cp4epsps gene (Fig. 1). Lanes 1-10 different transformed clones: 1-15 (lane 1), 2-8 (lane 2), 3-17 (lane 3), 14-1 (lane 4), 15-23 (lane 5), 18-1 (lane 6), 19-10 (lane 7), 27-9 (lane 8), 29-15 (lane 9) and 33-2 (lane 10). Lane 11, Non-transgenic plant. Molecular size markers are indicated on the left

tolerance to glyphosate after 1 week (Fig. 3). In this assay, we observed that all sensitive plants showed symptoms of chlorosis 2 or 3 days after the herbicide treatment, and died 10 days later, while tolerant plants kept their green color (Fig. 3).

The $\mathrm{T}_{1}$ progeny of these ten transgenic lines was screened according to tolerance to the glyphosate herbicide. All lines transferred the cp4epsps gene in a Mendelian fashion. Although the Chi square $\left(\chi^{2}\right)$ tests showed that the segregation ratios for lines 1 and 33 fit the Medelian segregation of $3: 1$, it is highly probable that these lines segregate according
Fig. 4 PCR analysis of transformed plants with the plasmid pCP4EPSPS. Lane 1 positive control (plasmid pCP4EPSPS), Lane 2 molecular marker (1 kb ladder-Promega), Lanes 3-14 Transformed lines $(1,2,3,14$, $15,18,19,27,29,33,34,44)$ showing amplification of the cp4epsps gene, Lane 15 nontransformed plant

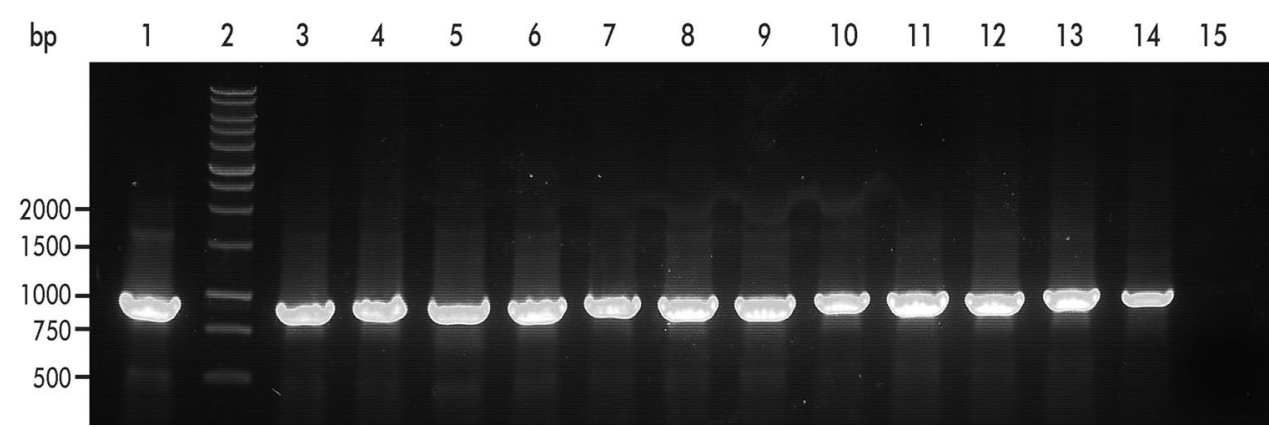

epsps Kpn I

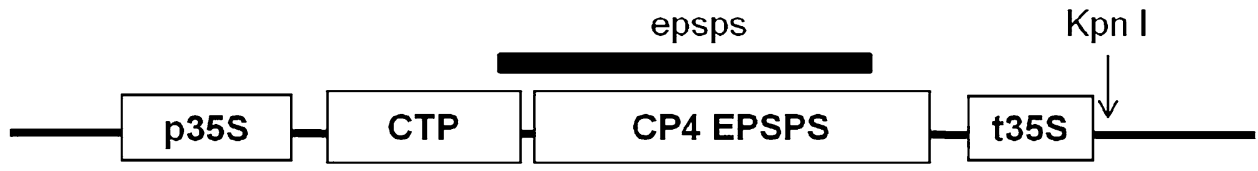

Fig. 5 Schematic representation of a fragment of the pCP4EPSPS plasmid used for soybean transformation. p35S CaMV 35S promoter; CTP transport to chloroplast peptide; cp4epsps gen codifying to
CP4EPSPS protein that conferred resistance to glyphosate herbicide; t35S terminator of $35 S$; $k p n I$ restriction enzyme used for DNA digestion and epsps indicates the probe for Southern blot analysis 
the ratio of 15:1 (Table 3). These plants grew and produced seeds, thus reaching generation $\mathrm{T}_{2}$.

\section{Molecular confirmation of the cp4epsps gene in the offspring}

The soybean lines $\left(T_{1}\right)$ growing in the greenhouse and selected in glyphosate were also tested by PCR and $100 \%$ of these samples showed the expected amplification product of $887 \mathrm{bp}$ corresponding to the cp4epsps gene. No amplification was visible in the untransformed control line (Fig. 4). Ten random transgenic lines selected in glyphosate were submitted to Southern blot analysis to confirm the integration of the transgene in the $T_{2}$ generation and the number of transgene integration sites. DNA digested with KpnI and probed with a cp4epsps fragment (Fig. 5) revealed an independent integration pattern for each transgenic line larger than $10 \mathrm{~kb}$. Although an effective differentiation of these patterns is not achieved, the lines exhibit two to three copies of the transgene (Fig. 6). Southern blot analysis allowed us to confirm that the cp4epsps fragment was integrated into the soybean genome. DNA isolated from non-transformed plants did not hybridize with the cp4epsps probe (Fig. 6).

\section{Discussion}

The genetic transformation of soybean is a very difficult process and its success depends on its combination with an efficient regeneration system (Homrich et al. 2012). Our laboratory first optimized the regeneration of shoots using the embryogenic axes of mature seeds of the Incasoy-36 Cuban soybean variety, characterized by its excellent agronomic features (Ortiz et al. 2008). These explants were able to regenerate shoots after 10 to 15 days in the MSB5 medium, following their induction with $5 \mathrm{mg} / \mathrm{L}$ benzylaminopurine (data not shown). The high content of benzylaminopurine favored the formation of multiple shoots in different soybean explants (Kim et al. 2004), which is very important in increasing the transformation efficiency of this recalcitrant crop (Aragão et al. 2000; Wang and Xu 2008; Zhang et al. 2014). Here we combined genetic transformation by bombardment of the soybean, with a regeneration system using the embryogenic axes because this type of explant is easier to obtain, the meristems show high proliferation and a large number of shoots regenerate in less time (Liu et al. 2004).

In the particle bombardment transformation of the soybean, positive results were found when bombarding at high pressure (Sato et al. 1993; Aragão et al. 2000; Cunha et al. 2011) and at low pressure (Droste et al. 2002), either with one or several impacts. A transient transformation system using GUS as reporter gene was employed to optimize the parameters for the bombardment of the embryogenic axes.
A high transient expression level of the GUS gene was confirmed in the transformed tissues after $48 \mathrm{~h}$ in benzylaminopurine. The blue staining of the explants were more intense in regions characterized by their strong cell division ability, as are the apical meristems of the embryogenic axes (Fig. 1a). Similar results were obtained in other soybean genotypes transformed by particle bombardment (Aragão et al. 2000) and by Agrobacterium tumefaciens (Liu et al. 2004) after an induction period in benzylaminopurine. Here we observed a more intense blue staining in some explants that were bombarded 2 and 3 times. There were, however, no significant differences in the number of stained explants when comparing the explants submitted to one, two or three bombardments.

The optimum glyphosate concentration was established for the selection of the explants having a stable transformation with the pCP4EPSPS plasmid. To minimize the presence of false positives it is essential to define the lowest concentration of the selection agent that consistently inhibits untransformed cell development (Conner 1986). The time required for selection with the herbicide must also be defined in order to achieve the effectiveness of the normal regeneration of transgenic shoots (Fig. 1d), as occurring in this transformation procedure. There were 46 shoots selected in $25 \mathrm{mg} / \mathrm{L}$ of glyphosate in these experiments (Table 2), which spent up to 60 days under that selection pressure. The regeneration of leaves, some small shoots and deformed shoots were found after 60 days; these were not considered in the calculation of the transformation frequency since the glyphosate can decrease its selection capacity after that time. Our result confirms the convenience of using a herbicide as the selection agent to generate tolerant shoots from the bombarded embryogenic axes (Aragão et al. 2000; Rech et al. 2008; Cunha et al. 2011). Other authors have also demonstrated that the use of selection agents to produce transgenic shoots ensures high soybean transformation frequencies (Aragão et al. 2000; Clemente et al. 2000; Dang and Wei 2007).

By bombarding the embryogenic axes after selection with imazapyr, a high soybean transformation frequency, generating 5-7 shoots per embryogenic axis, was reported by Aragão et al. (2000). Ten percent of these regenerated shoots were able to grow in length. In our case, although only $1-2$ shoots per explant were regenerated, all of them were able to grow in length and root. This produced a high transformation frequency (up to $6.0 \%$ ), which was achieved with the efficient selection of the shoots in $25 \mathrm{mg} / \mathrm{L}$ of glyphosate (Table 2). These results are comparable with those reported for the Brazilian cultivars DOKO RC (4.7\%) and BR-91(3.9\%) obtained through selection in imazapyr (Aragão et al. 2000). It was recently reported that 22 transgenic soybean lines were obtained using Agrobacterium and selection with $15 \mathrm{mg} / \mathrm{L}$ of glyphosate. Only 4 transgenic 
plants, however, showed high tolerance to this herbicide (Guo et al. 2015).

Glyphosate is considered an effective selection agent for soybean transformation (Clemente et al. 2000; Guo et al. 2015). This type of herbicide is transported through the vascular system of the embryogenic axes and it later concentrates within the apical meristem region, which is the region used for the introduction of the transgene. It is therefore possible to carry out cell selection without affecting the embryogenic axes (Rech et al. 2008). We have demonstrated in these experiments that the use of the glyphosate herbicide as the selection agent in the culture medium produced a fast and effective system for selecting transformed meristematic cells. The molecular analyses made on transformed lines confirmed the presence of the transgene in the $\mathrm{T}_{1}$ and $\mathrm{T}_{2}$ generations, showing an independent integration pattern in the 10 transgenic lines analyzed. On the other hand, although primary chimeric transgenic plants have been found when they are transformed by the bombardment of meristematic tissues (Aragão et al. 1996), no chimeric plants were observed in soybean because of the efficient selection of glyphosate tolerant plants. This is confirmed by studying the segregation of herbicide resistance in the $T_{1}$ generation, which showed a Mendelian inheritance in the lines studied (Table 3 ).

When the plants of the selected transgenic lines were sprayed with glyphosate under greenhouse conditions, sensitive plants became visibly affected, showing chlorosis and withering. These symptoms were also observed in all nontransgenic plants used as controls, which eventually died. Similar symptoms of discoloration, chlorosis and decreased growth were reported by other authors in non-transgenic plants after the application of glyphosate (Chhapekar et al. 2015). This occurs because the herbicide is mainly concentrated in the metabolically active tissues, such as the immature leaves, shoots and roots, thus affecting the plants (Moldes et al. 2008). In contrast, the glyphosate tolerant transgenic plants maintained their intense green color after sprayed with the herbicide (Fig. 3), although some of them showed slight withering in the smallest leaves of the apical region of the plants, which later recovered. Other reports reveal that the chlorophyll content also decreases in herbicide tolerant soybean plants after being sprayed with the Roundup herbicide; these plants were able to recover their green color after 2 weeks (Nandula et al. 2007; Guo et al. 2015). This may occur because of the accumulation of phytotoxic metabolites, such as shikimic acid in the plant meristems (Reddy et al. 2004; Zobiole et al. 2012; Guo et al. 2015).

Our results suggest that with the selection designed with the glyphosate herbicide no chimeric plants will be produced. False positive plants surviving selection with the herbicide had previously been reported, and this could be the result of the unstable integration of the transgene in the plant genome (Huang and Wei 2005). The regeneration of soybean shoots in the presence of glyphosate took place during a short period of time (15-35 days), after which the plants rooted in a medium without any selection pressure, favoring in vitro growth. Although the soybean plants were submitted to a short selection period with the herbicide, no false positive plants were observed; this was demonstrated in the molecular analysis of generations $\mathrm{T}_{1}$ and $\mathrm{T}_{2}$ (Figs. 4, 5). Here we demonstrate the advantage of combining selection in glyphosate with the transformation of embryogenic axes to achieve the efficient transformation of soybean. This optimized transformation procedure may be used in other soybean genotypes and for the introduction of other genes associated to traits of agronomic interest.

Acknowledgments The authors are grateful to Dr. Miriam Ribas Hermelo by the language edition of the manuscript and Ernesto Galban Rodriguez for his help with the correction of figures. The authors would like to thank to the reviewers for their critical comments which helped to improve the quality of the manuscript.

Authors contributions NS, genetic transformation, molecular analysis and writing of the manuscript. $\mathrm{CD}$, genetic transformation and greenhouse evaluation. $\mathrm{YH}$, tissue culture and statistical analysis. $\mathrm{YR}$, plasmid construction. AF, tissue culture. MP, writing and review of the manuscript. FJLA, experimental design and review of the manuscript. GAE, experimental design and review of the manuscript.

\section{Compliance with ethical standards}

Conflict of interest The authors declare that there are no conflicts of interest.

\section{References}

Aragão F, Barros L, Brasileiro A, Ribeiro S, Smith F, Sanford J, Faria J, Rech E (1996) Inheritance of foreign genes in transgenic bean (Phaseolus vulgaris L.) co-transformed via particle bombardment. Theor Appl Genet 93(1-2):142-150

Aragão F, Sarokin L, Vianna G, Rech E (2000) Selection of transgenic meristematic cells utilizing a herbicidal molecule results in the recovery of fertile transgenic soybean [Glycine max (L.) Merril] plants at a high frequency. Theor Appl Genet 101(1-2):1-6

Aragão FJ, Vianna GR, Carvalheira SB, Rech EL (2005) Germ line genetic transformation in cotton (Gossypium hirsutum L.) by selection of transgenic meristematic cells with a herbicide molecule. Plant Sci 168(5):1227-1233

Chhapekar S, Raghavendrarao S, Pavan G, Ramakrishna C, Singh VK, Phanindra MLV, Dhandapani G, Sreevathsa R, Kumar PA (2015) Transgenic rice expressing a codon-modified synthetic CP4EPSPS confers tolerance to broad-spectrum herbicide, glyphosate. Plant Cell Rep 34(5):721-731

Christou P (1996) Transformation technology. Trends Plant Sci 1(12):423-431

Christou P, Swain W, Yang N, McCabe D (1989) Inheritance and expression of foreign genes in transgenic soybean plants. Proc Natl Acad Sci 86:7500-7504

Clemente TE, La Vallee BJ, Howe AR, Conner-Ward D, Rozman RJ, Hunter PE, Broyles DL, Kasten DS, Hinchee MA (2000) Progeny 
analysis of glyphosate selected transgenic soybeans derived from Agrobacterium-mediated transformation. Crop Sci 40:797-803

Cobb AH, Reade JP (2010) Auxin-type herbicides. Herbicides and Plant Physiology, Second Edition, Second Edition: 133-156

Conner A (1986) Isolation and characterisation of variants from plant cell culture. New Zealand J Technol 2(2):83-94

Cunha NB, Murad AM, Cipriano TM, Araújo ACG, Aragão FJ, Leite A, Vianna GR, McPhee TR, Souza GH, Waters MJ (2011) Expression of functional recombinant human growth hormone in transgenic soybean seeds. Transgenic Res 20(4):811-826

Dang W, Wei Z-M (2007) An optimized Agrobacterium-mediated transformation for soybean for expression of binary insect resistance genes. Plant Sci 173(4):381-389

de Paiva Rolla AA, Carvalho JdFC, Fuganti-Pagliarini R, Engels C, Do Rio A, Marin SRR, de Oliveira MCN, Beneventi MA, Marcelino-Guimaraes FC, Farias JRB (2014) Phenotyping soybean plants transformed with rd29A: AtDREB1A for drought tolerance in the greenhouse and field. Transgenic Res 23(1):75-87

Dill GM, CaJacob CA, Padgette SR (2008) Glyphosate-resistant crops: adoption, use and future considerations. Pest Manag Sci 64(4):326-331

Dill GM, Sammons RD, Feng PC, Kohn F, Kretzmer K, Mehrsheikh A, Bleeke M, Honegger JL, Farmer D, Wright D (2010) Glyphosate: discovery, development, applications, and properties. Glyphosate resistance in crops and weeds: history, development, and management. John Wiley and Sons, Inc, Hoboken:1-33

Doyle J, Doyle J (1987) A rapid DNA isolation procedure for small quantities of fresh leaf tissue. Phytochem Bulletin 19:11-15

Droste A, Pasquali G, Bodanese-Zanettini M (2000) Integrated Bombardment and Agrobacterium transformation system: an alternative method for soybean transformation. Plant Mol Biol Rep 18:51-59

Droste A, Pasquali G, Bodanese-Zanettini M (2002) Transgenic fertile plants of soybean [Glycine max (L.) Merrill] obtained from bombarded embryogenic tissue. Euphytica 127:367-376

Ferguson BJ (2013) The development and regulation of soybean nodules. INTECH Open Access Publisher

Finer JJ, Larkin K (2008) Genetic transformation of soybean using paticle bombardment and SAAT approaches. In: Kirti PB (ed) Handbook of new technologies for genetic improvement of legumes. pp 103-123

Finer J, McMullen D (1991) Transformation of soybean via particle bombardment of embryogenic suspension culture tissue. In Vitro Cell Dev Biol-Plant 27:175-182

Gamborg O, Miller R, Ojima K (1968) Nutrient requirements of suspension cultures of soybean root cells. ExpCell Res 50:151-158

Guo B, Guo Y, Hong H, Jin L, Zhang L, Chang R-Z, Lu W, Lin M, Qiu L-J (2015) Co-expression of G2-EPSPS and glyphosate acetyltransferase GAT genes conferring high tolerance to glyphosate in soybean. Front Plant Sci 6:847

Hinchee M, Connor-Ward D, Newell C, McMonnell R, Sato S, Gasser C, Fischhoff D, Re D, Fraley R, Horsch R (1988) Production of transgenic soybean plants using Agrobacterium - mediated DNA transfer. Biotechnology 6:915-922

Homrich M, Wiebke-Strohm B, Weber R, Bodanese-Zanettini M (2012) Soybean genetic transformation: a valuable tool for the functional study of genes and the production of agronomically improved plants. Genetics Mol Biol 35(4):998-1010

Horak MJ, Rosenbaum EW, Kendrick DL, Sammons B, Phillips SL, Nickson TE, Dobert RC, Perez T (2014) Plant characterization of roundup ready 2 yield $^{\circledR}$ soybean, MON 89788, for use in ecological risk assessment. Transgenic Res 24(2):213-225

Huang X, Wei Z (2005) Successful Agrobacterium-mediated genetic transformation of maize elite inbred lines. Plant Cell Tiss Organ Cult 83:187-200

Jefferson RA (1987) Assaying chimeric genes in plants: the GUS gene fusion system. Plant Mol Biol Rep 5(4):387-405
Kanizay LB, Jacobs TB, Gillespie K, Newsome JA, Spaid BN, Parrott WA (2015) HtStuf: High-throughput sequencing to locate unknown DNA junction fragments. Plant Genome 8(1)

Kim Y, Park T, Kim H, Park H, Chon S, Yun S (2004) Factors affecting organogenesis from mature cotyledon explants and regeneration in soybean. J Plant Biotechnol 6(1):39-43

Liu H, Yang C, Wei M (2004) Efficient Agrobacterium tumefaciensmediated transformation of soybean using an embryogenic tip system. Planta 219:1042-1049

Mariashibu T, Anbazhagan V, Jiang S, Ganapathi A, Ramachandan S (2013) In vitro regeneration and genetic transformation of soybean. In: James E (ed) Board, Published: January, vol 2

McCabe DE, Swain WF, Martinell BJ, Christou P (1988) Stable transformation of soybean (Glycine max) by particle acceleration. Nat Biotechnol 6(8):923-926

Menéndez C, Trujillo LE, Ramírez R, González-Peña D, Espinosa D, Enríquez GA, Hernández L (2014) Production of a liquid Bradyrhizobium japonicum inoculant with high impact on the mechanized sowing of soybean in Cuba. Biotecnología Aplicada 31(2):116-120

Moldes CA, Medici LO, Abrahao SO, Tsai SM, Azevedo RA (2008) Biochemical responses of glyphosate resistant and susceptible soybean plants exposed to glyphosate. Acta Physiol Plant 30:469-479

Mollenhauer C, Smart CC, Amrhein N (1987) Glyphosate toxicity in the shoot apical region of the tomato plant: I. Plastid swelling is the initial ultrastructural feature following in vivo inhibition of 5-enolpyruvylshikimic acid 3-phosphate synthase. Pesticide Biochem Physiol 29(1):55-65

Murashige T, Skoog F (1962) A revised medium for rapid growth and bioassay with tobacco tissue culture. Plant Physiol 15:473-479

Nandula VK, Reddy KN, Rimando AM, Duke SO, Poston DH (2007) Glyphosate-resistant and-susceptible soybean (Glycine max) and canola (Brassica napus) dose response and metabolism relationships with glyphosate. J Agric Food Chem 55(9):3540-3545

Olhoft P, Flagel L, Somers D (2004) T-DNA locus structure in a large population of soybean plants transformed using the Agrobacterium-mediated cotyledonary-node method. Plant Biotechnol J 2(4):289-300

Ortiz R, de la Fé C, Ponce M (2008) INCASoy-36: a new soybean variety obtained in Cuba from mutation induction by $60 \mathrm{Co}$ gamma rays. Cultivos Tropicales 29(3):73

Padgette S, Kolacz K, Delannay X (1995) Development, identification and characterization of a glyphosate-tolerant soybean event. Crop Sci 35:1451-1461

Parrott W, Williams E, Hildebrand D, Collins G (1989) Effect of genotype on somatic embryogenesis from immature cotyledons of soybean. Plant Cell Tiss Organ Cult 16(1):15-21

Paz M, Martínez J, Kalvig A, Fonger T, Wang K (2006) Improved cotyledonary node method an alternative explant derived from mature seed for efficient Agrobacterium-mediated soybean transformation. Plant Cell Rep 25:206-213

Rech E, Vianna G, Aragao F (2008) Hight-efficiency transformation by biolistics of soybean, common bean and cotton transgenic plants. Nat Protoc 3(3):410-418

Reddy KN, Rimando AM, Duke SO (2004) Aminomethylphosphonic acid, a metabolite of glyphosate, causes injury in glyphosatetreated, glyphosate-resistant soybean. J Agric Food Chem 52(16):5139-5143

Sambrook J, Fritsch E, Maniatis T (1989) Molecular cloning. In: A laboratory manual. Cold Spring Harbor, New York

Sato S, Newell C, Kolacz K, Tredo L, Finer J, Hinchee M (1993) Stable transformation via particle bombardment in two different soybean regeneration systems. Plant Cell Rep 12(7-8):408-413

Shaner DL (2009) Role of translocation as a mechanism of resistance to glyphosate. Weed Sci 57(1):118-123 
Simmonds D, Donaldson P (2000) Genotype screening for proliferative embryogenesis and biolistic transformation of short-season soybean genotypes. Plant Cell Rep 19(5):485-490

Verma K, Saini R, Rani A (2014) Recent advances in the regeneration and genetic transformation of soybean. J Innovative Biol 1:15-26

Wang G, Xu Y (2008) Hypocotyl-based Agrobacterium-mediated transformation of soybean (Glycine max) and application for RNA interference. Plant Cell Rep 27(7):1177-1184

Wiebke-Strohm B, Droste A, Pasquali G, Osorio MB, Bücker-Neto L, Passaglia LMP, Bencke M, Homrich MS, Margis-Pinheiro M, Bodanese-Zanettini MH (2011) Transgenic fertile soybean plants derived from somatic embryos transformed via the combined DNA-free particle bombardment and Agrobacterium system. Euphytica 177(3):343-354

Yang X-f, Yu X-q, Zhou Z, Ma W-J, Tang G-x (2016) A high-efficiency Agrobacterium tumefaciens mediated transformation system using cotyledonary node as explants in soybean (Glycine max L.). Acta Physiologiae Plantarum 38(3):1-10

Zhang Z, Gou Z, Shou H, Pegg S, Clemente T, Staswick P, Wang K (2000) Assessment conditions affecting Agrobacterium-mediated soybean transformation and routine recovery of transgenic soybean. In: Arencibia A (ed) Plant genetic engineering: towards the Third Millennium: Proceedings of the Internetional Symposium on Plant Genetic Engineering. Elsevier, New York, pp 88-94

Zhang F, Chen C, Ge H, Liu J, Luo Y, Liu K, Chen L, Xu K, Zhang Y, Tan G (2014) Efficient soybean regeneration and Agrobacteriummediated transformation using a whole cotyledonary node as an explant. Biotechnol Appl Biochem 61(5):620-625

Zobiole LHS, Kremer RJ, Constantin J (2012) Glyphosate effects on photosynthesis, nutrient accumulation, and nodulation in glyphosate-resistant soybean. J Plant Nutr Soil Sci 175(2):319-330 